\title{
Nutrient content and fatty acid profile of fermented shrimp (Litopenaeus vannamei) sausage
}

\author{
${ }^{1}$ Fitriana, L.Y., ${ }^{2}$ Maharani, N., ${ }^{1,3}$ Anjani, G. and ${ }^{1,3,{ }^{*}}$ Afifah, D.N., \\ ${ }^{I}$ Department of Nutrition Science, Faculty of Medicine, Universitas Diponegoro, Semarang, 50275, \\ Indonesia \\ ${ }^{2}$ Center for Biomedical Research (CEBIOR), Faculty of Medicine, Universitas Diponegoro, Semarang, \\ 50275, Indonesia \\ ${ }^{3}$ Center of Nutrition Research (CENURE), Universitas Diponegoro, Semarang, 50275, Indonesia
}

\section{Article history:}

Received: 9 March 2021

Received in revised form: 30

April 2021

Accepted: 2 May 2021

Available Online: 8 August 2021

Keywords:

Fatty acids,

Nutritional value,

Shrimp,

Sausage,

Fermentation

DOI:

https://doi.org/10.26656/fr.2017.5(S3).002

\begin{abstract}
Cardiovascular disease affects the heart or blood vessels and is preventable by feeding on functional food containing unsaturated fatty acids, such as shrimp. Fermentation increases the functional food value, such as shrimp, by breaking down complex compounds in carbohydrates, proteins, and fats, with enzymes and microorganisms. Hence, this research was aimed to determine the differences in the fatty acid and nutritional profiles of shrimp sausages in different fermentation duration. This was an experimental research with a randomized design in the form of three levels of fermentation duration, consisting of 24 , 48, and $72 \mathrm{hrs,}$, and without fermentation as a control, with three repetitions. The fermentation was carried out spontaneously using a salt concentration of $1.2 \%$, at $50^{\circ} \mathrm{C}$ for $3 \mathrm{hrs}$, and then reduced to $35^{\circ} \mathrm{C}$. Parameters measured were the fatty acid profile, moisture, ash, fat, protein, and carbohydrate. The fatty acid profile was presented descriptively, while the statistical analysis of nutritional values used the One-Way ANOVA, Kruskal-Wallis test, and continued with the post hoc examination. There are fifteen types of fatty acids in fermented shrimp sausage, and their values change during the fermentation process. The highest fatty acid group in the fermented shrimp sausage was polyunsaturated $(36.28 \% \mathrm{w} / \mathrm{w})$. There was a significant difference in the mean water and fat content with diverse duration $(\mathrm{p} \leq 0.05)$. However, there were no significant differences in the ash, protein, and carbohydrate content with different duration $(\mathrm{p} \geq 0.05)$. The duration of the fermentation process affects the fatty acids level and nutritional value of fermented shrimp sausage. The longer the fermentation process duration, the higher the fatty acid levels and the lower the water content, ash, and protein.
\end{abstract}

\section{Introduction}

Cardiovascular Disease (CVD) is known to be a leading cause of death globally. Approximately $85 \%$ of the cases are caused by heart attacks and strokes (WHO, 2017). The Basic Health Research in 2018 stated that $1.5 \%$ or 15 out of 1000 Indonesians suffer from this disease (Ministry of Health of the Republic of Indonesia, 2018).

Risk factors include obesity, smoking, abnormalities in lipid profiles, inadequate physical activity, diet with high fat and cholesterol, and low fibre intake (Rafiony, 2013). CVD can be prevented by consuming foods that contain fatty acids, such as PUFA and MUFA, with a PUFA ratio higher than MUFA (Erwianto et al., 2017).
The shrimp's fatty acid content is a high source of PUFAs, such as omega 3, eicosapentaenoic acid (EPA), and docosahexaenoic acid (DHA) in the muscles (Li et al., 2011; Michaelsen et al., 2011; Simon et al., 2012). Omega 3 intake is beneficial for heart disease and stroke by reducing cholesterol and triglyceride levels. Also, it increases blood vessels' elasticity and prevents the formation of harmful fats that stick to the arteries (Simopulus, 2016). EPA and DHA fatty acids are precursors of anti-inflammatory, antithrombotic, and vasodilatory activities, preventing dyslipidemia and hypertension (Food and Agriculture Organization, 2010; Simon et al., 2012).

A food's functional value increases through the fermentation process, which breaks down complex 
compounds, such as carbohydrates, proteins, and fats with enzymes and microorganisms (Hutkins, 2006). During fermentation, proteolytic enzymes break down proteins to free amino acids and peptides having bioactive properties, such as antioxidants and antihypertensive (Lee et al., 2008). Furthermore, the lipase enzyme and lactic acid bacteria hydrolyse fat resulting in much higher essential fatty acids (Magalhaes et al., 2011). Fish paste fermentation takes 8 to 32 days, resulting in an increase in the fatty acids content, namely capric, stearic and myristic acid, EPA, and DHA (Anggo, Ma'ruf and Et, 2015). In the fermentation study of sorghum flour, a decrease in carbohydrate content occurs in small amounts. This may be caused by microorganisms, which use it as an energy source during fermentation (Setiarto et al., 2016).

Seafood is rich in protein and is highly perishable, it has a short shelf life unless a preservation method is used. Preservation can take many forms. One of them is fermented sausage, a meat product mixed with spices and added to a starter culture to assist the fermentation process (Vural and Zvural, 2007). This is carried out uncontrollably by excluding microbes in a starter form. However, they play active roles by producing proteolytic enzymes that react with the product (Estiasih, 2009). Meanwhile, spontaneous fermentation is aided by adding $1.2 \%$ of salt (Honikel, 2008).

The fermentation process has a certain duration. Fermented catfish and tuna sausages have different $\mathrm{pH}$ values, whereas a longer fermentation duration has a lower $\mathrm{pH}$ level. Therefore, the longer the duration, the lower the $\mathrm{pH}$ value. Moreover, the fish protein undergoes hydrolysis into amino acids and peptides (Nursyam, 2011; Nisa and Wardani, 2016).

There is a dearth of information on fermented shrimp sausage. This research was conducted to determine the effect of duration variations of fermenting shrimp sausages on their fatty acid content and nutritional value.

\section{Materials and methods}

The research was conducted at the Food Laboratory of Nutrition Science, Faculty of Medicine, Universitas Diponegoro, using fermented shrimp sausage products. The fatty acid content analysis in the fermented sausages was carried out at the Integrated Laboratory of Bogor Agricultural University, West Java. Meanwhile, the nutrient content analysis (carbohydrates, fats, proteins, water, and ash) was carried out at the Food Technology Laboratory, Semarang State University. This research was an experimental study adopting a randomized design with one factor.

\subsection{Making fermented shrimp sausages}

The tools used in making fermented shrimp sausage were digital scales, basins, blenders, spoons, jars, ovens, and aluminium foil. The materials used were headless shrimp, ice water, salt, corn oil, sugar, garlic, pepper, tapioca flour, egg white, and liquid smoke.

The head of the shrimp was removed, then washed and soaked with $2 \%$ lime juice. After grinding the shrimp, shrimp paste with $12 \%$ ice water, $9.3 \%$ egg white, $7.5 \%$ tapioca flour, $3.1 \%$ corn oil, $1.2 \%$ salt, $1.2 \%$ granulated sugar, $0.6 \%$ garlic, and $0.2 \%$ pepper were mixed until homogenized and inserted into the edible shell.

The shrimp sausage was soaked in 5\% liquid smoke for $30 \mathrm{mins}$, then oven-dried at $50^{\circ} \mathrm{C}$ for $3 \mathrm{hrs}$. The cooked sausages were incubated at $35^{\circ} \mathrm{C}$ for 24,48 , and $72 \mathrm{hrs}$ to produce fermented shrimp.

\subsection{Analysis of fatty acids}

Three grams of fermented shrimp sausage was mashed using a mortar. Methylation formation was carried out by inserting $0.2 \mathrm{~g}$ oil and $5 \mathrm{~mL}$ of $0.5 \mathrm{~N}$ $\mathrm{NaOH}-m e t h a n o l$ into a test tube, then heated in a water bath for 20 mins at $80^{\circ} \mathrm{C}$. When the mixture reached room temperature, $5 \mathrm{~mL}$ of $\mathrm{BF}_{3}$ solution was added to the tube. The sample was reheated for another 20 mins in a water bath at $80^{\circ} \mathrm{C}$, then it was let to rest. Subsequently, $2 \mathrm{~mL}$ of saturated $\mathrm{NaCl}$ and $5 \mathrm{~mL}$ of hexane were added to the sample, then the mixture was shaken. The hexane solution at the top was collected into a test tube. A total of $1 \mu \mathrm{L}$ fat sample was injected into the gas chromatograph. The fatty acids were identified by a flame ionization detector and recorded with a chromatogram.

The fatty acid identification was carried out by balancing the sample retention time with the standard. The quantitative analysis was calculated using the following formula:

$\left(\right.$ Fatty Acid Identification $\left.=\frac{\text { fatty acid area } A}{\text { SI area }} \times R F \times \frac{m g S I}{m g \text { sample }}\right) \times 100$

The RF (Respond Factor) value of each fatty acid was calculated from the FAME external standard chromatogram.

RF of Fatty acid $A=\frac{\text { SI area }}{\text { SI concentration }} \times \mathrm{RF} \times \frac{\text { Standardized fatty acid A concentration }}{\mathrm{mg} \text { sample area of standardized fatty acid A }}$

\subsection{Analysis of nutritional content}

\subsubsection{Water content analysis}

Water content analysis was carried out by AOAC 2005 two times using the oven method. The porcelain dish was placed in the oven for 30 mins at $100-105^{\circ} \mathrm{C}$, then cooled in a desiccator and weighed. Approximately 
$2 \mathrm{~g}$ of the sample were dried in the oven for $6 \mathrm{hrs}$ at $100^{\circ}$ C. After the sample was cooled, the sample was repeatedly weighed until a constant weight was achieved.

Water content calculation:

Water content $(\%)=\frac{\text { weight }(g) \text { of sample before drying-weight }(g) \text { of dample before drying }}{\text { weight }(g) \text { of sample before drying }}$

\subsubsection{Ash content analysis}

The ash content analysis was carried out two times using the oven method. The porcelain dish was placed in the oven for $30 \mathrm{mins}$ at $100-105^{\circ} \mathrm{C}$, cooled, and weighed. Then, $2 \mathrm{~g}$ of the sample was weighed in the dish and burned over a flame until it did not smoke. Then, the ashing was carried out in a furnace at 550 $600^{\circ} \mathrm{C}$ for approximately $1 \mathrm{hr}$. The sample in a dish was then cooled in a desiccator and weighed. The combustion stage was repeated in the furnace until a constant weight was obtained.

Ash content calculation:

Ash Content $=\frac{(\text { A dish } \text { with ashed sample-initial dish weight })}{(\text { a dish with sample-initial dish weight })} \times 100 \%$

\subsubsection{Protein content analysis}

Protein content analysis was carried out using the Kjeldahl method. Approximately $1 \mathrm{~g}$ of the sample was placed in the Kjeldahl flask. The sample was added with $7 \mathrm{~g} \mathrm{~K}_{2} \mathrm{SO}_{4}, 0.8 \mathrm{~g} \mathrm{CuSO}_{4}$, and $200 \mathrm{~mL} \mathrm{H}_{2} \mathrm{SO}_{4}$ then heated for 75 mins. The solution was allowed to rest until it reaches room temperature before transferring it into a round bottom flask. The solution was rinsed with $25 \mathrm{~mL}$ of distilled water, then $50 \mathrm{~mL}$ of $40 \% \mathrm{NaOH}$ was added.

The solution was distilled in an Erlenmeyer containing $30 \mathrm{~mL}$ of $\mathrm{H}_{3} \mathrm{BO}_{3}$ and 3 drops of BCG-MR indicator. The result was titrated with $0.1 \mathrm{~N} \mathrm{HCl}$ till pink. Calculation:

$$
\begin{gathered}
\mathrm{N}(\mathrm{g})=\frac{(A-B)}{1000} \times \mathrm{N} \mathrm{HCl} \times 14.008 \times 100 \% \\
\mathrm{~N}(\%)=\frac{N(g)}{\text { sample weight }(\mathrm{g})} \times 100 \%
\end{gathered}
$$

$\%$ Crude protein $=\% \mathrm{~N} \times$ protein conversion factor

Where $\mathrm{A}=$ Volume of $\mathrm{HCl}(\mathrm{mL})$ used in the sample titration, $\mathrm{B}=$ volume of $\mathrm{HCl}(\mathrm{mL})$ used in the blank titration and the protein conversion factor $=6.25$.

\subsubsection{Fat content analysis}

The fat content was determined using the Soxhlet method. The flask with fat was dried in an oven at $105^{\circ} \mathrm{C}$ for $30 \mathrm{mins}$, then cooled for $15 \mathrm{mins}$ in a desiccator. A total of $2-5 \mathrm{~g}$ of the sample was placed on a filter paper, then tied with fat-free cotton wool. The fat solvent was placed in the flask, then the sample was inserted into a soxhlet extraction device. The extraction was carried out for 3-4 hrs, then distilled and dried in an oven at $105^{\circ} \mathrm{C}$ until it reached a constant weight, then cooled in a desiccator for 30 mins and weighed again. Calculation:

$$
\text { Fat content }=\frac{W 3-W 2}{W I} \times 100 \%
$$

Where $\mathrm{W} 1$ = sample weight $(\mathrm{g}), \mathrm{W} 2$ = the weight of beaker without fat $(\mathrm{g})$ and $\mathrm{W} 3=$ the weight of beaker with fat $(\mathrm{g})$.

\subsubsection{Carbohydrate content analysis}

The carbohydrate content analysis was carried out using the difference method by subtracting $100 \%$ from the percentage of water, ash, protein, and fat content.

Carbohydrate $(\%)=100 \%-(\%$ water $+\%$ ash $+\%$ protein $+\%$ fat)

\subsection{Data analysis}

The fatty acid data were obtained from the measurement results and presented descriptively, while data on nutritional value would be processed using a statistical software program. The data normality was tested using Shapiro-Wilk, since the data was $<50$. The water and fat content of fermented shrimp sausage were tested using ANOVA (Analysis of Variance) and continued with the post hoc Least Significance Different test. The ash, protein, and carbohydrate content of the fermented shrimp sausages were tested using KruskalWallis. The effect of the independent variable on the dependent was considered significant when the p-value was $\leq 0.05$.

\section{Results}

\subsection{Fatty acid profile}

There were 15 types of fatty acids obtained from the fermented shrimp sausages. The main fatty acids of fermented shrimp sausage in the Saturated Fatty Acid (SFA), MUFA, PUFA groups were palmitic acid (7.52\% $\mathrm{W} / \mathrm{W})$, oleic acid $(19.53 \% \mathrm{~W} / \mathrm{W})$, and linoleic acid $(36.28 \% \mathrm{~W} / \mathrm{W})$, respectively in the $72 \mathrm{hrs}$ of fermentation.

Total SFA increased at $24 \mathrm{hrs}$ of fermentation, then decreased at $48 \mathrm{hrs}$ and $72 \mathrm{hrs}$. Total MUFA decreased at $24 \mathrm{hrs}$ and $48 \mathrm{hrs}$ of fermentation, then increased at 72 hrs. PUFA group experienced a decrease in the total fatty acid content $24 \mathrm{hrs}$ of fermentation, then increased at 48 hrs and $72 \mathrm{hrs}$. The changes in the fatty acid composition of shrimp sausage during the fermentation period were not the same, as shown in Table 1.

\subsection{Nutrient content}

There was a significant difference in the water content of fresh shrimp and fermented shrimp sausage 
Table 1 . Fatty acid composition in shrimp and fermented shrimp sausage (\%W/W)

\begin{tabular}{|c|c|c|c|c|c|}
\hline \multirow{2}{*}{$\begin{array}{l}\text { Fatty acid } \\
\text { Saturated fatty acid (SFA) }\end{array}$} & \multicolumn{5}{|c|}{ The Duration of Shrimp Sausage Fermentation } \\
\hline & Fresh Shrimp & Without Fermentation & $24 \mathrm{hrs}$ & $48 \mathrm{hrs}$ & $72 \mathrm{hrs}$ \\
\hline Myristic acid (C14:0) & 0.08 & 0.03 & 0.05 & 0.05 & 0.03 \\
\hline Palmitic acid (C16:0) & 5.14 & 7.44 & 8.00 & 6.66 & 7.52 \\
\hline Heptadekanoat acid (C17:0) & 0.22 & 0.06 & 0.08 & 0.09 & 0.05 \\
\hline Stearic acid (C18:0) & 2.94 & 1.23 & 1.30 & 1.15 & 1.3 .0 \\
\hline Arachidic acid (C20:0) & 0.11 & 0.25 & 0.25 & 0.21 & 0.23 \\
\hline Heneikosanoat acid (C21:0) & 0.03 & 0.02 & 0.03 & 0.02 & 0.02 \\
\hline Behanic acid (C22:0) & 0.17 & 0.08 & 0.07 & 0.07 & 0.07 \\
\hline Lignoceric acid (C24:0) & 0.10 & 0.12 & 0.17 & 0.11 & 0.12 \\
\hline \multirow[t]{2}{*}{ Total } & 8.79 & 9.23 & 9.95 & 8.36 & 9.34 \\
\hline & $(37.30 \%)$ & $(12.40 \%)$ & $(16.70 \%)$ & $(13.60 \%)$ & $(14.10 \%)$ \\
\hline \multicolumn{6}{|c|}{ Monounsaturated fatty acid (MUFA) } \\
\hline Palmitoleic acid (C16:1) & 0.27 & 8.6 & 0.18 & 0.22 & 0.09 \\
\hline Oleic acid (C18:1n9c) & 3.16 & 19.81 & 20.3 & 17.73 & 19.53 \\
\hline \multirow[t]{2}{*}{ Total } & 3.43 & 28.41 & 20.48 & 17.95 & 19.62 \\
\hline & $(14.50 \%)$ & $(38.00 \%)$ & $(34.30 \%)$ & $(29.20 \%)$ & $(29.50 \%)$ \\
\hline \multicolumn{6}{|l|}{ Polyunsaturated fatty acid (PUFA) } \\
\hline Linoleic acid (C18:2n6c) & 5.97 & 36.06 & 28.78 & 34.00 & 36.28 \\
\hline Linolenic acid (C18:3n3) & 0.34 & 0.50 & 0.31 & 0.51 & 0.57 \\
\hline Arachidonic acid (C20:4n6) & 1.07 & 0.25 & 0.08 & 0.21 & 0.12 \\
\hline Eicosapentanoic acid (C20:5n3) & 1.91 & 0.15 & 0.1 & 0.25 & 0.24 \\
\hline Docosahexaenoic acid C22:6n3) & 2.07 & 0.08 & 0.04 & 0.14 & 0.21 \\
\hline \multirow[t]{2}{*}{ Total } & 11.36 & 37.04 & 29.31 & 35.11 & 37.42 \\
\hline & $(48.20 \%)$ & $(49.60 \%)$ & $(49.10 \%)$ & $(57.20 \%)$ & $(56.40 \%)$ \\
\hline Total fatty acid & 23.58 & 74.68 & 59.74 & 61.42 & 66.38 \\
\hline
\end{tabular}

Shrimp sausage consisted of $62.3 \%$ fresh shrimp and $37.7 \%$ filler materials

with different durations of fermentation $(p=0.043)$.

Table 2 showed that fresh shrimp had the highest water content (64.94\%) compared to fermented shrimp sausage without fermentation, 24-, 48-, and 72-hrs fermentation. The shrimp sausage with the highest water content was without fermentation $(51.44 \%)$, while the lowest was 72 hrs fermentation $(44.02 \%)$. The difference in ash content of fresh shrimp and fermented shrimp sausage with different fermentation duration was not significant ( $p=$ 0.068). Fresh shrimp had the lowest water content (64.94\%) compared to fermented shrimp sausage for 24 , 48, and $72 \mathrm{hrs}$ and without fermentation. The shrimp sausage with the highest water content was without fermentation $(0.89 \%)$, while the lowest was $72 \mathrm{hrs}$ fermentation $(0.86 \%)$. There was a significant difference in the fat content of fresh shrimp and fermented shrimp sausage with different fermentation duration $(p<0.001)$. Fresh shrimp had the lowest fat content (7.45\%) compared to fermented shrimp sausage for $24,48,72 \mathrm{hrs}$ and without fermentation. The shrimp sausage with the highest fat content was fermented for $72 \mathrm{hrs}(11.37 \%)$, while the lowest was without fermentation $(9.01 \%)$. The difference in protein content of fresh shrimp and fermented shrimp sausage with different fermentation duration was not significant $(p=0.068)$. Fresh shrimp had the highest protein content $(18.99 \%)$ compared to fermented shrimp sausage for 24, 48, $72 \mathrm{hrs}$ and without fermentation. The shrimp sausage with the highest protein content was without fermentation (12.93\%), while the lowest was $72 \mathrm{hrs}$ fermentation (9.21\%). The difference in carbohydrate content of fresh shrimp and fermented shrimp sausage with different fermentation duration was not significant $(p=0.068)$. Fresh shrimp had the lowest carbohydrate content $(64.94 \%)$ compared to fermented shrimp sausage for 24, 48, $72 \mathrm{hrs}$ and without fermentation. The shrimp sausage with the highest carbohydrate content was fermented for $72 \mathrm{hrs}$ $(34.54 \%)$, while the lowest was without fermentation $(25.72 \%)$.

\section{Discussion}

Shrimp contains nutrients rich in fat, protein, minerals, and vitamins (Larsen et al., 2011). It is also a source of Polyunsaturated Fatty Acids (PUFA), especially Eicosapentaenoic Acid (EPA) and Docosahexaenoic Acid (DHA) (Li et al., 2011).

The major fatty acid compositions in shrimp are 
Table 2. Nutrient analysis results of fermented shrimp sausage

\begin{tabular}{cccccc}
\hline \multirow{2}{*}{ Fermentation Duration } & \multicolumn{5}{c}{ Category } \\
\cline { 2 - 6 } & Water (\%) & Ash (\%) & Fat (\%) & Protein (\%) & Carbohydrate (\%) \\
\hline Fresh Shrimp & $64.94 \pm 0.101^{*}$ & $0.61 \pm 0.022$ & $7.45 \pm 0.052^{*}$ & $18.99 \pm 0.034$ & $8.03 \pm 0.622$ \\
Without Fermentation & $51.44 \pm 0.067^{*}$ & $0.89 \pm 0.006$ & $9.01 \pm 0.016^{*}$ & $12.93 \pm 0.091$ & $25.72 \pm 0.034$ \\
$24 \mathrm{hrs}$ & $49.91 \pm 0.065$ & $0.88 \pm 0.006$ & $9.96 \pm 0.017^{*}$ & $11.94 \pm 0.084$ & $27.31 \pm 0.304$ \\
$48 \mathrm{hrs}$ & $44.27 \pm 0.122^{*}$ & $0.87 \pm 0.005$ & $11.03 \pm 0.009^{*}$ & $10.49 \pm 0.074$ & $33.34 \pm 0.054$ \\
$72 \mathrm{hrs}$ & $44.02 \pm 15.434^{*}$ & $0.86 \pm 0.006$ & $11.37 \pm 0.010^{*}$ & $9.21 \pm 0.065$ & $34.54 \pm 0.190$ \\
\hline & $\mathrm{p}=0.043^{\mathrm{a}}$ & $\mathrm{p}=0.068^{\mathrm{b}}$ & $\mathrm{p}<0.001^{\mathrm{a}}$ & $\mathrm{p}=0.068^{\mathrm{b}}$ & $\mathrm{p}=0.068^{\mathrm{b}}$ \\
\hline
\end{tabular}

*Values that are significantly different, ${ }^{\mathrm{a}}$ ANOVA test, ${ }^{\mathrm{b}}$ Kruskal Wallis test.

linoleic (5.97\%), palmitic (5.14\%), oleic (3.16\%), stearic (2.94\%), DHA (2.07\%), EPA (1.91\%), and arachidonic acid $(1.07 \%)$. The variation of fatty acid composition was influenced by some factors such as species types, availability, and quality of feed, heat application, season changing, and environmental salinity (Simopoulos, 2016; Pires et al., 2018).

The total fatty acid without fermentation had the highest composition value $(74.68 \%)$ due to the addition of corn oil as a source of linoleic (34-62\%), oleic (19$49 \%$ ), and palmitic acid (8-12\%) (Dwiputra, 2015). The reduction of arachidonic acid, EPA, and DHA occurred in this study was inconsistent with the results of Mekarsari's research, which suggested that the increase in EPA was influenced by the increase in phenol having a role in inhibiting fat oxidation. However, the DHA content was undetected due to the nature of essential fatty acids; they are sensitive to temperature, light, and oxygen (Swastawanti and Sumardianto, 2004; Mekarsari et al., 2016).

Our results showed that PUFA and MUFA levels decreased at $24 \mathrm{hrs}$ of fermentation. Decreased linoleic acid in soy sauce fermentation occurs on the 30 th day. This is because fermentation accelerates the oxidation process (Haman et al., 2017; Zou et al., 2019). Meanwhile, the oxidation process was influenced by the meat quality, temperature, exogenous components (salt, nitrate, seasonings), and fumigation (Talon et al., 2000; Nassu et al., 2003).

The shrimp sausage fermentation at 48 hrs showed an increase in PUFA and MUFA. However, at $72 \mathrm{hrs,}$ there was a decrease in EPA, arachidonic, palmitoleic, myristic and stearic acid. Visesanguan's et al. (2006) study showed an increase in PUFA and MUFA fatty acids at the end of the 72 hrs fermentation of Nahm sausage. The lipolytic activity was influenced by enzymes from the muscle tissue or lipases from microorganisms that released fatty acids (Gambacorta et al., 2009). The Lactic Acid Bacteria (LAB) reduced the $\mathrm{pH}$ for lipolytic and proteolytic enzymes (Montel et al., 1998). The fermentation of fish paste decreased some of the essential fatty acids at $72 \mathrm{hrs}$. The lipolysis process increases certain fatty acids and produces a distinctive flavour in fermented products (Murray et al., 2003).

The American Dietetic Association and Dietitians of Canada recommended the consumption of $500 \mathrm{mg} /$ day of EPA + DHA for primary prevention of cardiovascular disease. Meanwhile, according to FAO/WHO, 250-2000 $\mathrm{mg} /$ day of $\mathrm{EPA}+\mathrm{DHA}$ was recommended for the secondary prevention of cardiovascular disease. The recommended consumption of fermented shrimp sausages to carry out these needs was 50-100 g/day (Kris -Etherton et al., 2007; FAO/WHO, 2008).

The water content was a parameter related to the shelf life of a product. Our result shows that the highest water content was fresh shrimp. The lowest was fermented shrimp sausage with $72 \mathrm{hrs}$ of fermentation, which was consistent with the study by Ferreira et al. (2006), who reported that water content decreased after fermentation (Ferreira et al., 2006). The research by Yanuar et al. (2015) and Swastawanti et al. (2004) showed a decrease in water content, which was influenced by temperature and smoking duration due to the evaporation in the smoked milkfish. Cellulose sleeves had pores that facilitated water expulsion from the sausages during the smoking process. The fermentation process decreased the $\mathrm{pH}$ value and increased the meat structure bonds. Therefore, the waterbinding capacity decreased and was easily removed from the product (Soepomo, 2015). The addition of salt and sugar also decreased the water content due to the ion's hydration attracting water molecules in the food ingredient (Staf et al., 2014).

Ash is an inorganic residue from the combustion process of organic compounds showing the total minerals in the food ingredients (Andarwulan et al., 2011; Winarno, 2008). The results showed that the highest ash content was $0.86 \%$ in fermented shrimp sausage with $72 \mathrm{hrs}$ of fermentation. This meets the Indonesian National Standard requirements, allowing ash content in seafood to be less than 3\% (Badan Standarisasi Nasional (BSN), 1995). Mumpuni (2017) demonstrated no difference in the fermented sausage treatment since there was no variation in the 
concentration of raw materials and seasonings. The ash content increased due to the addition of mineral substances to the spices. Liquid smoking lowered the ash content due to the loss of organic elements, such as carbon, sulfur, and phosphorus (Yanuar et al., 2015). Nisa and Wardani's (2016) study on fermentation of catfish sausage showed a decrease in ash content due to minerals from microorganisms to sustain life. More than 19 minerals, dissolved by water and fat, were released during the process and it took a long period to ferment (Silfia et al., 2017).

Fat is a lipid compound that produces more energy than protein or carbohydrate (Hutomo et al., 2015). There was a difference in the mean of fat content $(p<0.001)$ in the shrimp sausages that fermented at 0 and 24 hrs, which means the fat content did not in accordance with the standard. The addition of corn oil increased fat since it contained $14 \mathrm{~g}$ of fat per one tablespoon. The research on smoking eels showed that the fat content increased, but was not significantly different. This indicated that using liquid smoke could maintain the raw material's quality without breaking down the fat composition (Hutomo et al., 2015). Nisa and Wardani's (2016) research showed that the fat content of fermented catfish sausages was increased steadily. The Lactic Acid Bacteria (LAB) had a secondary lipolytic activity which broke down the fat into simple chemical compounds. The lipase enzyme controlled this activity by releasing fatty acids (Nisa and Wardani, 2016).

Protein is a molecule composed of amino acids as a tissue-building substance and a regulator of the digestion process (Winarno, 2008). The result of this research showed that the lowest protein content was $9.21 \%$ in fermented shrimp sausage with $72 \mathrm{hrs}$ of fermentation. The Indonesian National Standard suggested that protein content in seafood was $6.9-15.5 \%$ (BSN, 1995). However, it decreased due to the addition of lime juice. The research by Asrullah et al. (2012) explained that adding $1 \mathrm{~mL}$ of lime juice caused a decrease in fish protein content due to amino acid racemization. The longer the protein reacted with the acid, the higher the peptide bonds were hydrolyzed. As a result, it damaged the protein's primary structure. Swastawanti et al. (2014) showed that the longer heating damaged the smoked fish protein, denatured its structure, coagulated, and became a simpler form. The protein content was decreased during the fermentation process. That result is consistent with previous studies where protein content in shrimp paste decreases during the fermentation process (Anggo et al., 2014). Therefore, the protein compounds were broken down into their derivatives, such as proteolysis, peptone, peptides, and amino acids. (Nooryanti et al., 2010).
Carbohydrates are the primary energy source consisting of carbon, hydrogen, and oxygen. There was no difference in the mean carbohydrate content $(\mathrm{p}=$ 0.068 ) for each treatment and it exceeded the standard between 10.2-20.9\%. The addition of ingredients, such as tapioca flour and sugar increased the carbohydrate content of the raw material (shrimp). The smoking process increased the carbohydrates, which is consistent with Yanuar et al. (2015) that the longer and higher the temperature, the higher the carbohydrate content. However, in this study, the carbohydrate content results were obtained from the calculation formula and not based on laboratory analysis (Yanuar et al., 2015). There was starch hydrolysis by enzymes into derivatives during the fermentation process, such as glucose and maltose (Rahayu and Puwoko, 2005). Moreover, decreased water content during the fermentation process will increase carbohydrate levels.

\section{Conclusion}

The fermentation process produced different types of fatty acids. In general, the shrimp sausage's fatty acid content of the shrimp sausage, so-called PUFA (37.42\% $\mathrm{w} / \mathrm{w})$, increased at $72 \mathrm{hrs}$ of the fermentation process. There was a significant difference between the mean of water and fat content of the shrimp sausage in different fermentation duration $(24,48,72 \mathrm{hrs}$, and without fermentation), with $p<0.05$. There was no significant difference between the mean of ash, protein, and carbohydrates content of shrimp sausage in different fermentation duration $(0,24,48$, and $72 \mathrm{hrs})$, with $\mathrm{p}>$ 0.05 .

\section{Conflict of interest}

The authors declare there is no conflict of interest.

\section{Acknowledgments}

The researchers are grateful to the Higher Education Fundamental Research and the Directorate of Research and Community Service Directorate General of Strengthening Research and Development of Ministry of Research, Technology and Higher Education to fund this study.

\section{References}

Andarwulan, N., Kusnandar, F. and Herawati, D. (2011). Analisis Pangan. Jakarta, Indonesia: Dian Rakyat. [In Bahasa Indonesia].

Anggo, A.D., Swastawati, F. and Ma'ruf, W.F. (2014). Mutu organoleptik dan kimiawi terasi shrimp rebon dengan kadar garam berbeda dan lama fermentasi. Jurnal Pengolahan Hasil Perikanan Indonesia, 17 
(1), 53-59. https://doi.org/10.17844/ jphpi.v17i1.8137. [In Bahasa Indonesia].

Anggo, A.D., Ma'ruf, W.F., Swastawati, F. and Rianingsih, L. (2015). Changes of amino and fatty acids in anchovy (Stolephorus $s p$ ) fermented fish paste with different fermentation periods. Procedia Environmental Sciences, 23, 58-63. https:// doi.org/10.1016/j.proenv.2015.01.009

Asrullah, M., Mathar, A.H., Citrakesumasari, N.J. and Fatimah, S. (2012). Denaturasi dan daya cerna protein pada proses pengolahan lawa bale (makanan tradisional Sulawesi Selatan). Media Gizi Masyarakat Indonesia, 1(2), 3-10. [In Bahasa Indonesia].

Badan Standarisasi Nasional (BSN). (1995). Sosis Daging. SNI-01-3820-1995. Indonesia: BSN. [In Bahasa Indonesia].

Dwiputra, D. (2015). Minyak Jagung Alternatif Pengganti Minyak yang Sehat. Jurnal Aplikasi Teknologi Pangan, 4(2). https://doi.org/10.17728/ jatp.2015.09. [In Bahasa Indonesia].

Erwianto, Santosa, A., Putranto, J.N.E., Tedjasukmana, P., Suryawan, R., Rifqi, S. and Kasiman, S. (2017). Panduan Tata Laksana Dislipidemia 2017. 1st ed. Indonesia: Centra Communication. [In Bahasa Indonesia].

Estiasih, T. (2009). Teknik Pengolahan Pangan. Indonesia: Bumi Aksara. [In Bahasa Indonesia].

FAO/WHO. (2008). Interim Summary of Conclusions and Dietary Recommendations on Total Fat and Fatty Acids. Rome: FAO.

Ferreira, V., Barbosa, J., Vendeiro, S., Mota, A., Silva, F., Monteiro, M.J., Hogg, T., Gibbs, P. and Teixeira, P. (2006). Chemical and microbiological characterization of alheira: A typical Portuguese fermented sausage with particular reference to factors relating to food safety. Meat Science, 73(4), 570-575.

https://doi.org/10.1016/ j.meatsci.2006.02.011

Food and Agriculture Organization. (2010). Fats and Fatty Acids in Human Nutrition: Report of an Expert Consultation. Rome: FAO.

Gambacorta, G., Sinigaglia, M., Schena, A. and Baiano, A., Lamacchia, C., Pati, S. and La Notte, E. (2009). Changes in free fatty acid and diacylglycerol compounds in short ripening dry-cured sausage. Journal of Food Lipids, 16(1), 1-18. https:// doi.org/10.1111/j.1745-4522.2009.01128.x

Haman, N., Romano, A., Asaduzzaman, M., Ferrentino, G., Biasioli, F. and Scampicchio, M. (2017). A microcalorimetry study on the oxidation of linoleic acid and the control of rancidity. Talanta, 164, 407-
4127. https://doi.org/10.1016/j.talanta.2016.12.012

Honikel, K.O. (2008). The use and control of nitrate and nitrite for the processing of meat products. Meat Science, 78(1-2), 68-76. https://doi.org/10.1016/ j.meatsci.2007.05.030

Hutkins, R.W. (2006). Microbiology and Technology of Fermented Foods. IFT Press. https:// doi.org/10.1002/9780470277515

Hutomo, H.D., Swastawati, F. and Rianingsih, L. (2015). Pengaruh konsentrasi asap cair terhadap kualitas dan kadar kolesterol belut. Pengolah dan Bioteknologi Hasil Perikanan, 4(1), 7-14. [In Bahasa Indonesia].

Kris-Etherton, P.M., Innis, S. and Assocition, A.D. (2007). Position of the American Dietetic Association and Dietitians of Canada: Dietary fatty acids. Journal of the American Dietetic Association, 107(9), 1599-1611. https://doi.org/10.1016/ j.jada.2007.07.024

Larsen, R., Eilertsen, K.E. and Elvevoll, E.O. (2011). Health benefits of marine foods and ingredients. Biotechnology Advances, 29(5), 508-518. https:// doi.org/10.1016/j.biotechadv.2011.05.017

Lee, M.-K., Lee, J.-K., Son, J.-A., Kang, M.-H., Koo, K. -H. and Suh, J.-W. (2008). S-adenosyl-1-methionine (SAM) production by lactic acid bacteria strains isolated from different fermented kimchi products. Food Science and Biotechnology, 17(4), 857-860.

Li, G., Sinclair, A.J. and Li, D. (2011). Comparison of lipid content and fatty acid composition in the edible meat of wild and cultured freshwater and marine fish and shrimps from China. Journal of Agricultural and Food Chemistry, 59(5), 1871-1881. https:// doi.org/10.1021/jf104154q

Magalhaes, K.T., Pereira, G.V. de M., Campos, C.R., Dragone, G. and Scehwan, R.F. (2011). Brazilian kefir: Structure, microbial communities and chemical composition. Brazilian Journal of Microbiology, 42(2), 693-702. https:// doi.org/10.1590/S1517-83822011000200034

Mekarsari, T.K.W., Swastawanti, F. and Susanto, E. (2016). Pengaruh perbedaan lama perendaman dalam asap cair tempurung kelapa terhadap profil lemak cumi-cumi. Jurnal Pengolahan dan Bioteknologi Hasil Perikanan, 5(2), 35-42. [In Bahasa Indonesia].

Michaelsen, K.F., Dewey, K.G., Perez-exposito, A.B., Nurhasan, M., Lauritzen, L. and Roos, N. (2011). Review Article Food sources and intake of n-6 and $n$ -3 fatty acids in low-income countries with emphasis on infants, young children (6-24 months), and pregnant and lactating women. Maternal and Child Nutrition, 7(S2), 124-140. https://doi.org/10.1111/ j.1740-8709.2011.00302.x 
Ministry of Health of the Republic of Indonesia. (2018). Riset Kesehatan Dasar (Riskedsas). Jakarta: Kementrian Kesehatan. Jakarta, Indonesia: Ministry of Health of the Republic of Indonesia. [In Bahasa Indonesia].

Montel, M.C., Masson, F. and Talon, R. (1998). Bacterial role in flavour development. Meat Science, Supplement 1, S111-S123. https://doi.org/10.1016/ S0309-1740(98)90042-0

Mumpuni, N.D.S. (2012). Kandungan Nutrisi serta Asam amino pada Sosis Fermentasi Probiotik dengan Kultur Lactobacillus plantarum $2 \mathrm{C} 12$ atau Lactobacillus acidophilus 2B4. Bogor, Indonesia: Institut Pertanian Bogor. [In Bahasa Indonesia].

Murray, R., Granner, D., Mayes, P. and Rodwell, V. (2003). Harper's Illustrated Biochemistry (TwentySix). New York: McGraw Hill Companies Inc.

Nassu, R.T., Gonlcalves, L.A.G., da Silva, M.A.A.P. and Besera, F.J. (2003). Oxidative stability of fermented goat meat sausage with different levels of natural antioxidant. Meat Science, 63(1), 43-49. https:// doi.org/10.1016/S0309-1740(02)00051-7

Nisa, A.K. and Wardani, A.K. (2016). Pengaruh lama pengasapan dan lama fermentasi terhadap sosis fermentasi ikan lele (Clarias gariepinus). Jurnal Pangan Dan Agroindustri, 4(1), 367-376.

Nooryanti, S., Yusphina, F. and Rita, K. (2010). Kualitas terasi udang dengan suplementasi Pediococcus halophilus (FNCC-0033). Jurnal Hasil Perikanan, 1, 11-26. https://doi.org/10.20527/fs.v1i1.1176. [In Bahasa Indonesia].

Nursyam, H. (2011). Pengolahan sosis fermentasi ikan tuna (Thunnus sp.) menggunakan kultur starter Lactobacillus plantarum terhadap nilai $\mathrm{pH}$, total asam, N-Total dan N-aAmino. Jurnal Ilmiah Perikanan Dan Kelautan, 3(2), 221-228. [In Bahasa Indonesia].

Pires, D.R., de Morais, A.C.N., Coelho, C.C.S., Marinho, A.F., Góes, L.C.D.S.A., Augusta, I.M., Ferreira, F.S. and Saldanha, T. (2018). Nutritional composition, fatty acids and cholesterol levels in Atlantic white shrimp (Litopenaeus schimitti). International Food Research Journal, 25(1), 151157.

Rafiony, A. (2013). Konsumsi fastfood dan softdrink sebagai faktor risiko obesitas pada remaja SMA di Kota Pontianak. Indonesia: Univerisitas Gadjah Mada. [In Bahasa Indonesia].

Rahayu, A. and Purwoko, T. (2005). Analisis karbohidrat, protein, dan lemak pada pembuatan kecap lamtoro gung (Leucaena leucocephala) terfermentasi Aspergillus oryzae. Bioteknologi, 2(1),
14-20. https://doi.org/10.13057/biotek/c020103 [In Bahasa Indonesia].

Setiarto, R.H.B., Widhyastuti, N. and Iwan, S. (2016). Pengaruh fermentasi fungi, bakteri asam laktat dan khamir terhadap kualitas nutrisi tepung sorgum. Agritech, 36(4), 444. https://doi.org/10.22146/ agritech.16769 [In Bahasa Indonesia].

Silfia., S. Kamsina, K., Diza, Y.H. and Hermianti, W. (2017). Pengaruh jenis starter untuk meningkatkan efisiensi waktu fermentasi dan analisis proksimat biji kakao. Jurnal Litbang Industri, 7(1), 53-60. https:// doi.org/10.24960/jli.v7i1.2792.53-60. [In Bahasa Indonesia].

Simon, S.J.G.B., Sancho, R.A.S., Lima, F.A., Cabral, C.C.V.Q., Souza, T.M., Bragagnolo, N. and Lira, G.M. (2012). Interaction between soybean oil and the lipid fraction of fried pitu prawn. LWT - Food Science and Technology, 48(1), 120-126. https:// doi.org/10.1016/j.lwt.2012.02.015

Simopoulos, A.P. (2016). An increase in the omega-6/ omega-3 fatty acid ratio increases the risk for obesity. Nutrients, 8(3), 1634-1638. https:// doi.org/10.3390/nu8030128

Soepomo. (2005). Ilmu dan Teknologi Daging. Yogyakarta, Indonesai: Gadjah Mada University Press. [In Bahasa Indonesia].

Swastawanti, F. and Sumardianto. (2004). Pengaruh lama waktu pengasapan terhadap komposisi DHA (Docosahexaenoic Acids) ikan bandeng. Indonesia: Direktorat Jenderal Pendidikan Tinggi, Departement Pendidikan Nasional. [In Bahasa Indonesia].

Swastawati, F., Darmanto, Y.S., Sya'Rani, L., Kuswanto, K.R. and Taylor, K.D.A. (2014). Quality characteristics of smoked skipjack (Katsuwonus pelamis) using different liquid smoke. International Journal of Bioscience, Biochemistry and Bioinformatics, 4(2), 94. https://doi.org/10.7763/ IJBBB.2014.V4.318

Talon, R., Walter, D. and Montel, M.C. (2000). Growth and effect of staphylococci and lactic acid bacteria on unsaturated free fatty acids. Meat Science, 54(1), $41-47$. 00068-6

Visessanguan, W., Benjakul, S., Riebroy, S., Yarchai, M. and Tapingkae, W. (2006). Changes in lipid composition and fatty acid profile of Nham, a Thai fermented pork sausage, during fermentation. Food Chemistry, 94(4), 580-588. https://doi.org/10.1016/ j.foodchem.2004.11.051

Vural, H. and Zvural, E.O. (2007). Fermented sausage from other meats. In Toldrá, F. and Ames, I. (Eds.), Fermented Meat and Poultry. United Kingdom: 
Blackwell.

https://

doi.org/10.1002/9780470376430.ch35

WHO. (2017). Cardiovascular diseases (CVDs). Retrieved on May 1, 2019 from WHO website: https://www.who.int/news-room/fact-sheets/detail/ cardiovascular-diseases-(cvds)\#: : text=CVDs $\%$ 20 are $\% 20$ the $\% 20$ number $\% 201$,to $\% 20$ heart $\%$ 20attack\%20and\%20stroke

Winarno, F.G. (2008). Kimia Pangan dan Gizi. (2008). Jakarta, Indonesia: Gramedia Pustaka Utama. [In Bahasa Indonesia].

Yanuar, D., Prasetyo, B., Darmanto, Y.S. and Swastawati, F. (2015). Efek Perbedaan Suhu dan Lama Pengasapan terhadap Kualitas Ikan Bandeng (Chanos chanos Forsk) Cabut Duri Asap. Jurnal Aplikasi Teknologi Pangan, 4(3), 94-98. https:// doi.org/10.17728/jatp.v4i3.134 [In Bahasa Indonesia].

Zou, M., Zhu, X., Li, X. and Zeng, X. (2019). Changes in lipids distribution and fatty acid composition during soy sauce production. Food Science and Nutrition, 7(2), 764-772. https://doi.org/10.1002/ fsn3.922 